\title{
Relações entre satisfação, competência, saúde e absenteísmo no trabalho em uma grande instituição bancária pública
}

Vitor Hugo Bernstorff

Curso: Doutorado em Sociologia

Data da defesa: 13 de dezembro de 2007

Nome do orientador: Prof. Dr. Sadi Dal Rosso

\section{Resumo}

Este estudo teve como objetivo correlacionar satisfação profissional, avaliação de desempenho por competência individual, exame de saúde ocupacional e as estratégias de resistência caracterizadas pelas formas de absenteísmo no trabalho. Foram avaliados os dados de 28.230 trabalhadores de um grande banco público brasileiro. Identificaram-se cinco categorias da satisfação profissional: o conteúdo do trabalho, o salário, o ambiente social, as condições físicas e o aprendizado. A competência individual foi avaliada numa perspectiva de 360 graus, na qual atuam o superior hierárquico, pares, subordinados eo próprio trabalhador, atribuindo-se um valor ao desempenho humano na competitividade organizacional. A saúde ocupacional foi medida pelo estresse emocional e sintomas do DORT (Distúrbio Osteomuscular Relacionado ao Trabalho). O absenteísmo no trabalho foi medido por: ausência voluntária não abonada, licença-saúde $<=15$ dias e licença-saúde $>15$ dias.

Conclui-se que há um efeito espelho da satisfação, no qual cada categoria da satisfação influencia as demais positivamente tendendo ao prazer no trabalho e que o maior efeito negativo sobre 
a satisfação profissional é o excesso de trabalho, intensificação da flexibilização produtiva. Evidencia-se também a importância do significado do trabalho, pois pessoas inseridas nos locais adequados, e que vêem sentido no que fazem, agregam valor aos aspectos econômicos e sociais da organização.

Conclui-se também que o modelo de desempenho por competência individual aplicado pela empresa, repleto de desubjetivação, é inócuo e merecedor de descrédito. Outra conclusão é que o estresse ocupacional sofre muita influência da intensificação do trabalho e pelas atividades sem desafios num ambiente social individualizante e sem cooperação, inclusive de gênero.

Por fim, concluímos que o estresse e o DORT, concomitantemente com a insatisfação profissional, promovem uma resistência individual ao trabalho através da licença-saúde de curta duração (<=15 dias) relacionada com o desgaste e o limite de tolerância frente às condições e à organização do trabalho, num enfrentamento psicodinâmico e como estratégia da reflexividade. Essas ausências imprevisíveis são expressivas e nocivas econômica e socialmente à organização do trabalho e à qualidade da vida humana.

Palavras-chave: satisfação profissional, desempenho individual, gestão por competências, saúde ocupacional, estresse emocional, DORT, absenteísmo no trabalho, intensificação do trabalho, Banco do Brasil. 